\title{
Effect of pentagastrin on histamine output from the stomach in patients with duodenal ulcer
}

\author{
W K MAN, J H SAUNDERS, C INGOLDBY, AND J SPENCER \\ From the Department of Surgery, Royal Postgraduate Medical School, \\ Hammersmith Hospital, London
}

SUMMARY The role of histamine in acid secretion is controversial. Improvements in the techniques of histamine assay allow a better assessment of the relationship of histamine to acid secretion. Patients with duodenal ulcers were studied to determine the mucosal histamine responses to pentagastrin stimulation to relate the appearance of histamine in the gastric juice to acid production during stimulation, and to detect changes in the plasma histamine concentration during pentagastrin stimulation. There was a mean $27 \%$ fall (range $0-60 \%$ ) in mucosal histamine concentration after pentagastrin. The output of histamine into gastric juice closely paralleled acid output in peak output acid duration. The histogram profiles of acid and histamine were similar in shape. In contrast with previous studies, plasma histamine concentration was found to rise during peak acid secretion (mean rise $65 \%$ ). There was no relationship between initial mucosal histamine concentration and acid secretion or maximal gastric juice histamine. The association of histamine and gastric acid release found in these studies was so close that a functional relationship may be presumed. Our data are compatible with the hypothesis that pentagrastrin acts on the parietal cell indirectly by causing histamine release in the gastric mucosa, which in turn releases acid from the parietal cells.

Histamine has been postulated to play a vital role in the mediation of gastric acid secretion. In all animal species relatively high histamine levels are found in the gastric mucosa in the glandular region where acid is produced. In rat, gastrin and vagusstimulating drugs mobilise mucosal histamine, reducing the mucosal histamine store after stimulation of gastric acid production, ${ }^{12}$ and stimulation of gastric acid secretion by gastrin reduces the mucosal histamine store. ${ }^{1}$ Similarly, administration of insulin and reserpine caused a marked lowering of the gastric mucosal histamine level coincident with the production of gastric acid. ${ }^{2}$ These observations initiated various hypotheses that the endogenous histamine plays a vital role in the production of gastric acid, although some investigators have doubts about these concepts. ${ }^{3}$

In rat gastric mucosa histamine is most abundant in the body and associated with high parietal cell density. ${ }^{4}$ A similar histamine distribution is found in human gastric mucosa. ${ }^{5}$ However, there is a species difference in the cell types for the endogenous histamine store. In rat, histamine is mainly in the enterochromaffin and enterochromaffin-like cells, ${ }^{6}$ ?

Received for publication 12 May 1981 while, in man, it is predominantly stored in the mast cells.

Duodenal ulcer disease is associated with gastric hypersecretion and hyperchlorhydria. Patients with duodenal ulcer have a significantly lower gastric mucosal histamine concentration than normal control subjects. ${ }^{8}$ This may be related to a state of high mobilisation of endogenous mucosal histamine. Theoretically, released histamine may be detectable in the gastric juice and in the venous blood simultaneously during stimulated acid secretion.

With the advance of gastroscopy and methods for the accurate assay of minute quantities of histamine in various biological specimens, histamine concentrations can be determined in the gastric mucosa, in the gastric aspirate, and in the venous blood plasma. We have therefore undertaken a study in patients with duodenal ulcer to determine the changes in histamine concentration in mucosa, plasma, and gastric juice after stimulation with pentagastrin.

\section{Methods}

PATIENTS

Patients with duodenal ulcer diagnosed clinically, radiologically, and confirmed at endoscopy were included in the present study. Gastric mucosal 
biopsies were obtained at gastroscopy and assayed for histamine. After the gastroscopy, all patients received a standard 90 minute pentagastrin infusion test $(6 \mu \mathrm{g} / \mathrm{kg} / \mathrm{h})$ routinely performed in the clinic with collection of fractions every 10 minutes. $^{9}$ Patients gave informed consent to a second endoscopy immediately after the conclusion of the pentagastrin infusion test to obtain biopsy specimens for histamine assay. Nineteen patients underwent a pentagastrin infusion test. Six patients had a pentagastrin infusion test in which blood samples for histamine assay were taken at 10 minute intervals.

\section{Histamine in gastric mucosa}

The method of fluorometric assay of histamine is based on that of Troidl and co-workers. ${ }^{8}$ Three biopsy specimens were taken at a fixed position of $45 \mathrm{~cm}$ from the mouth of the patient on the anterior gastric wall. They were frozen immediately in liquid nitrogen and stored at $-20 \mathrm{C}$ for not more than one week before assay. The tissue was thawed on ice, weighed, and homogenised in $0.5 \mathrm{ml}$ ice-cold $0.4 \mathrm{M}$ perchloric acid (tissue grinder, Gallenkamp). The homogeniser was washed through with three portions of $0.5 \mathrm{ml}$ cold perchloric acid. The pooled acid solution was centrifuged at $2000 \mathrm{~g}$ at $4^{\circ} \mathrm{C}$ for 10 minutes. The supernatant was adjusted to $\mathrm{pH} 6.5$ with sodium hydroxide solution and $0.1 \mathrm{M}$ sodium phosphate buffer $\mathrm{pH} 6.5$ solution. The solution was immediately applied onto a short Dowex 50W-X8, 200-400 mesh column $(0 \cdot 3 \times 2 \mathrm{~cm})$ equilibrated with $0.1 \mathrm{M}$ sodium phosphate buffer. The column was then washed, in succession, with $5 \mathrm{ml}$ phosphate buffer, $1 \mathrm{ml}$ deionised water, and $5 \mathrm{ml} 1.0$ hydrochloric acid. The extracted histamine was eluted from the column by $3 \mathrm{ml} 4 \mathrm{M}$ hydrochloric acid solution. The fluorometric assay of histamine was performed on a reaction mixture which consisted of $0.5 \mathrm{ml}$ eluate, $0.5 \mathrm{ml}$ water, $0.5 \mathrm{ml} \times 5 \mathrm{M}$ sodium hydroxide, and $0.1 \mathrm{ml}$ o-phthalaldehyde $(1 \%$ in methanol). The mixture was incubated at room temperature for two minutes and the reaction was stopped by the addition of $1 \mathrm{ml} 1 \mathrm{M}$ orthophosphoric acid. The fluorescence was measured in an Aminco Bowman Spectrofluorometer (standardised with a polymer fluorescence standard) at an excitation wavelength of $360 \mathrm{~nm}$ and an emission wavelength of $450 \mathrm{~nm}$.

\section{Histamine in gastric aspirate}

Gastric juice was kept on ice after aspiration from the patient during the pentagastrin infusion test. Ten millilitres of the fluid were treated with $1 \mathrm{ml}$ $2 \mathrm{M}$ hydrochloric acid and $0.5 \mathrm{ml} 10 \%$ sodium tungstate solution to remove glycoprotein (such treatment does not interfere with the histamine assay as shown by three separate internal standard tests with and without sodium tungstate). The solution was centrifuged at $2000 \mathrm{~g}$ at $4^{\circ} \mathrm{C}$ for 10 minutes and the supernatant applied onto a Dowex column after titration to $\mathrm{pH} 6 \cdot 5$. The columnatographic procedures were identical with those for biopsy histamine assay.

Because the concentration of histamine in the gastric juice is very low (less than $50 \mathrm{mmol} / \mathrm{ml}$ ), it is necessary to have a further histamine extraction procedure to remove any interfering material which may affect the fluorometric assay. The method of Shore et $a l .^{10}$ is added to the present Dowex method and is called the 'combined method' by Lorenz et al. ${ }^{1011}$

The $3 \mathrm{ml}$ eluate after columnatography was treated with $1.5 \mathrm{~g}$ sodium chloride, $2.5 \mathrm{ml} 5 \mathrm{M}$ sodium hydroxide, and $10 \mathrm{ml} \mathrm{n}$-butanol. The content was mixed on a vertical rotating mixer for 20 minutes and centrifuged at $1000 \mathrm{~g}$ for five minutes. Eight $\mathrm{ml}$ of the butanol phase was pipetted into a container with $3 \mathrm{ml} 0.1 \mathrm{M}$ hydrochloric acid and $14 \mathrm{ml} \mathrm{n}$-heptane. The solution was mixed for six minutes and centrifuged for five minutes. The top organic layer was discarded.

The reaction mixture for the fluorometric asay of histamine consisted of $2 \mathrm{ml}$ aqueous phase from the Shore procedures, $0.4 \mathrm{ml} 1 \mathrm{M}$ sodium hydroxide, and $0.1 \mathrm{ml}$ o-phthalaldehyde $(0.1 \%$ in methanol). The mixture was incubated at room temperature for four minutes and the reaction was stopped by $0 \cdot 2$ $\mathrm{ml} 3 \mathrm{M}$ hydrochloric acid. The fluorescence was measured as for biopsy histamine assay. The results were not corrected for gastroduodenal loss and duodenogastric reflux.

\section{Histamine in blood plasma}

Because the concentration of histamine in human blood plasma is very low (less than $5 \mathrm{pmol} / \mathrm{ml}$ ), the enzymatic isotopic method described by Shaff and Beavan was used. ${ }^{12}$

The reaction mixture consisted of $0.1 \mathrm{ml}$ blood plasma, $\quad 0.05 \mathrm{ml}$ S-adenosyl-L-(methyl-3H) methionine (1-25 working dilution of the radiochemical supplied by Amersham, $15 \mathrm{Ci} \mathrm{mmol}^{-1}$ ), $0.075 \mathrm{ml}$ enzyme solution (1 in 40 working dilution of the enzyme preparation from male SpragueDawley rats, as described by Shaff and Beavon), and $0.40 \mathrm{ml} 0.1 \mathrm{M}$ sodium phosphate buffer, $\mathrm{pH} 7.9$. External histamine standards consisted of 0.11 to $50 \mathrm{pmol}$ histamine in 0.1 human albumin plasma protein fraction supplied by Immuno, which had been columnatographed three times through Dowex ion-exchange resins to remove all residual histamine. The solution was incubated at $37^{\circ} \mathrm{C}$ for 90 minutes and the reaction was stopped by the addition of 
$0.2 \mathrm{ml} \mathrm{M}$ perchloric acid containing unlabelled methylhistamine $(252 \mathrm{nmol} / 0 \cdot 2 \mathrm{ml})$. The precipitated protein was removed by centrifugation. $0.6 \mathrm{ml}$ of the supernatant was pipetted into a glass tube fitted with a screw cap. After the addition of $0.2 \mathrm{ml} 10 \mathrm{M}$ sodium hydroxide the labelled and unlabelled methylhistamine were extracted into $4 \mathrm{ml}$ chloroform. The chloroform extract was washed once with 0.5 $\mathrm{ml} 3.3 \mathrm{M}$ sodium hydroxide. $3 \mathrm{ml}$ aliquots were transferred to counting vials, evaporated to dryness in vacuum, and assayed for radioactivity in scintillation fluid (Emulsifier Scintillator 299, Packard).

A 19-gauge needle was inserted into a brachial vein of the patient receiving the pentagastrin infusion. Two millilitres of blood were withdrawn at 10 minute intervals during the test and transferred to an ice-cold polypropylene tube containing EDTA as anticoagulant. The blood sample was centrifuged at $2000 \mathrm{~g} 4^{\circ} \mathrm{C}$ for 15 minutes. Three $0.1 \mathrm{ml}$ aliquots of the top plasma from the tube were assayed for histamine by the enzymatic isotopic method. The mean value of the three determinations represented the histamine concentration of the blood plasma sample and was expressed in $\mathrm{pmol} / \mathrm{ml}$.

\section{Sensitivity and precision of methods}

The lowest limit of histamine assay by the fluorometric method performed in our laboratory is 20 pmol histamine. Recovery of authentic histamine added to the biopsy specimen in amounts of 543.2 pmol was $96.4 \% \mathrm{SD} \pm 7.3 \%(\mathrm{n}=8)$ and, when the same amount of histamine was added to the gastric aspirate, the recovery was $91.2 \pm 6.1 \%$ $(\mathrm{n}=8)$.

The lowest limit of histamine assay by the enzymatic isotopic method performed is 0.05 pmol histamine in the reaction mixture. Recovery of authentic histamine added to the plasma samples in amount of $0.68 \mathrm{pmol}$ was $87.3 \pm 17.6 \%(n=6)$.

\section{STATISTICAL ANALYSIS}

Statistical comparisons were made using the MannWhitney $U$ test, Wilcoxon match-pairs signed-rank test, and paired $t$ test as appropriate. $\mathrm{P}$ valuès $<0.05$ are recorded as statistically significant.

\section{Results}

MUCOSAL HISTAMINE CONCENTRATION

In one patient the mucosal histamine concentration remained unchanged; in the other 10 it was reduced after pentagastrin stimulation (Fig. 1). The mean mucosal histamine before pentagastrin was 287 $\mathrm{nmol} / \mathrm{g} \pm \mathrm{SD} 167$, and the mean mucosal histamine after pentagastrin was $218 \pm 150$ (paired $t$ test $\mathrm{P}<0.01$ ).

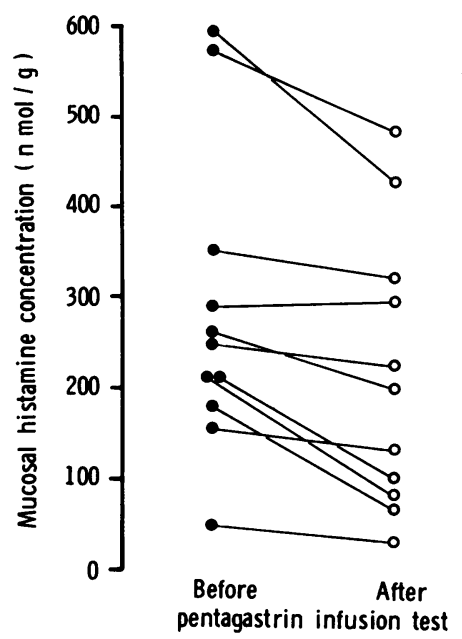

Fig. 1 Effect of pentagastrin on mucosal histamine.

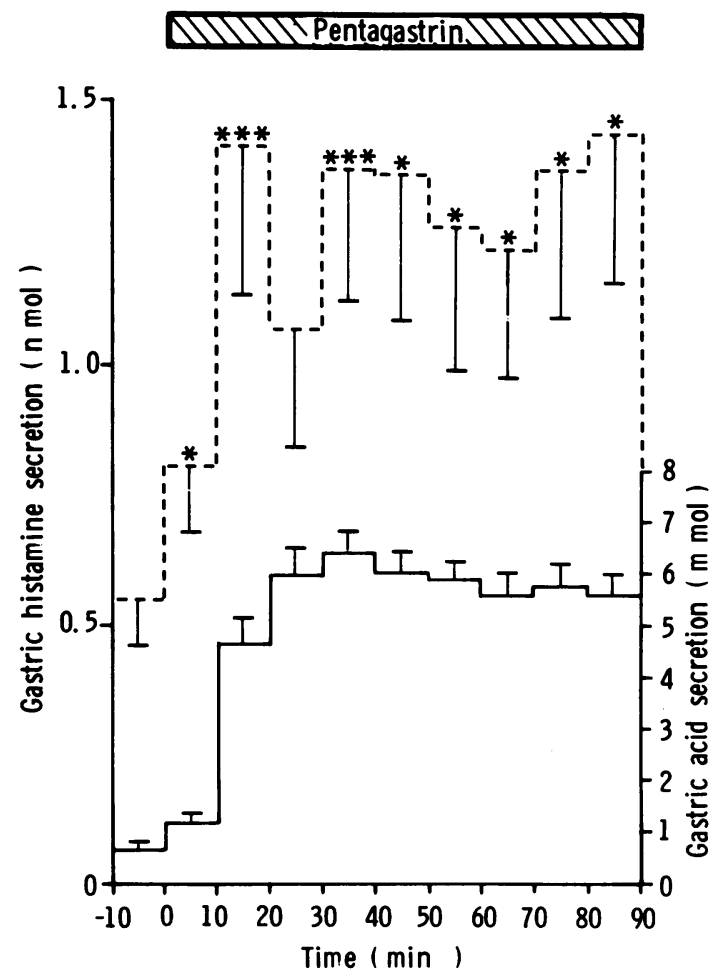

Fig. 2 Output of acid (solid line) and histamine (interrupted line in gastric juice during pentagastrin infusion: $n=19$; Bar $=S E M ; *_{\mathrm{P}}<0.05 ; * * * \mathrm{p}<0.001$. 


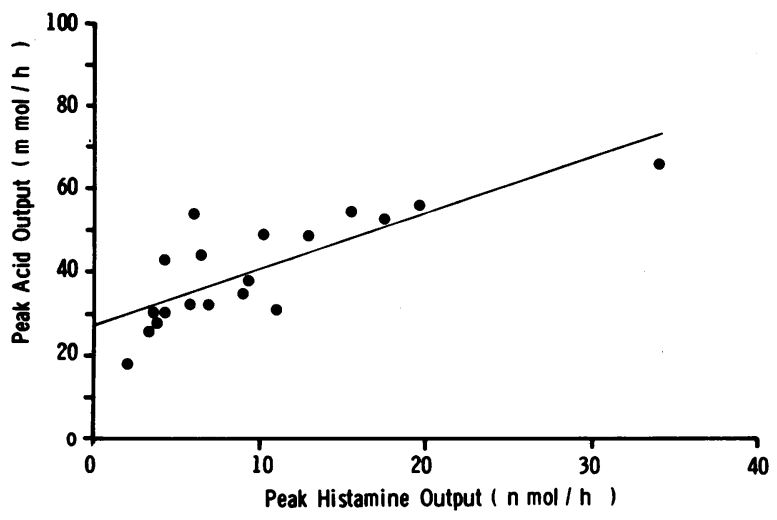

Fig. 3 Relationship between the peak output of acid and histamine in gastric juice during pentagastrin infusion; $n=19 ; r=0.79 ; \mathrm{P}<0.001$.

Fig. 4 Relationship between total acid and histamine output during pentagastrin infusion: $n=19$; $r-0.57 ; \mathrm{P}<0.02$.

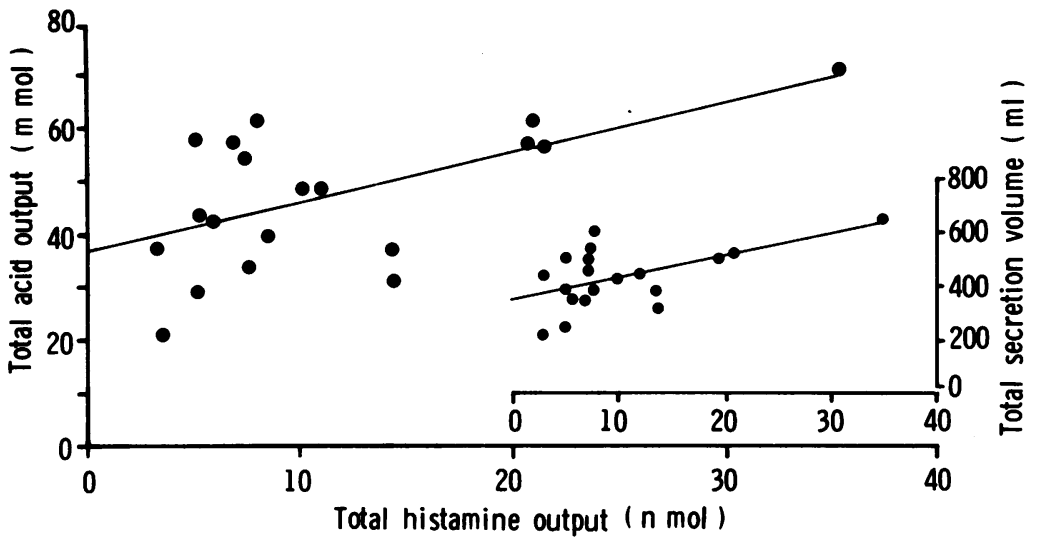

Table Histamine and pentagastrin stimulated gastric acid secretion

\begin{tabular}{|c|c|c|c|c|c|c|c|c|c|c|c|}
\hline \multirow[t]{2}{*}{ Patient } & \multicolumn{2}{|c|}{$\begin{array}{l}\text { Mucosal histamine } \\
\text { nmollg wt }\end{array}$} & \multicolumn{3}{|c|}{ Secretion volume during test } & \multicolumn{3}{|c|}{ Acid output during test } & \multicolumn{3}{|c|}{$\begin{array}{l}\text { Histamine in gastric juice during } \\
\text { test }\end{array}$} \\
\hline & Before & After & $\frac{\text { Basal }}{m l / h}$ & Maximum & $\begin{array}{l}\text { Total } \\
\text { ml/90, }\end{array}$ & $\frac{\text { Basal }}{\mathrm{mmol} / \mathrm{h}}$ & Peak & $\begin{array}{l}\text { Total } \\
\text { mmol/90, }\end{array}$ & $\frac{\text { Basal }}{n m o l / h}$ & Peak & $\begin{array}{l}\text { Total } \\
\text { nmol } / 90^{\circ}\end{array}$ \\
\hline WW & 246 & 227 & 264 & 600 & 649 & $16 \cdot 14$ & $65 \cdot 8$ & $70 \cdot 3$ & - & $34 \cdot 2$ & $35 \cdot 3$ \\
\hline BM & 154 & 137 & 102 & 294 & 383 & 0 & $32 \cdot 4$ & $39 \cdot 7$ & - & $7 \cdot 0$ & $8 \cdot 4$ \\
\hline JI & 599 & 432 & 78 & 435 & 498 & 0 & $52 \cdot 7$ & $56 \cdot 6$ & - & $17 \cdot 6$ & $21 \cdot 4$ \\
\hline JL & 255 & 199 & 192 & 480 & 533 & $9 \cdot 4$ & $55 \cdot 0$ & $61 \cdot 5$ & $1 \cdot 3$ & $15 \cdot 5$ & $21 \cdot 0$ \\
\hline JM & 312 & & 60 & 327 & 362 & 0 & $32 \cdot 4$ & $33 \cdot 9$ & 1.6 & $5 \cdot 7$ & $7 \cdot 5$ \\
\hline ND & 341 & & 54 & 273 & 313 & $3 \cdot 7$ & $34 \cdot 5$ & $37 \cdot 6$ & 3.0 & 9.0 & $14 \cdot 4$ \\
\hline CK & 198 & & 60 & 438 & 446 & $4 \cdot 4$ & 48.9 & $49 \cdot 1$ & $3 \cdot 4$ & 13.0 & $12 \cdot 2$ \\
\hline PB & - & & 78 & 327 & 386 & 0.1 & $30 \cdot 3$ & $31 \cdot 6$ & 6.6 & $11 \cdot 0$ & $14 \cdot 2$ \\
\hline JI & 341 & 326 & 72 & 396 & 451 & $3 \cdot 4$ & $54 \cdot 4$ & $8 \cdot 0$ & $2 \cdot 0$ & 6.0 & $7 \cdot 0$ \\
\hline DP & - & & 90 & 357 & 521 & $2 \cdot 0$ & $42 \cdot 7$ & 58.7 & 1.8 & $4 \cdot 3$ & $5 \cdot 1$ \\
\hline WB & 50 & 33 & 126 & 303 & 445 & $4 \cdot 7$ & $38 \cdot 3$ & $48 \cdot 8$ & $5 \cdot 4$ & $9 \cdot 4$ & $10 \cdot 1$ \\
\hline IK & 500 & & 228 & 402 & 612 & $10 \cdot 0$ & $49 \cdot 3$ & $62 \cdot 0$ & $6 \cdot 2$ & 10.4 & 8.0 \\
\hline CB & - & & 108 & 276 & 389 & 6.4 & $30 \cdot 1$ & $43 \cdot 2$ & 1.5 & $3 \cdot 8$ & 5.9 \\
\hline IK & 294 & 297 & 156 & 327 & 447 & $4 \cdot 3$ & 26.0 & $37 \cdot 8$ & $2 \cdot 5$ & $3 \cdot 5$ & $3 \cdot 2$ \\
\hline QG & 164 & 72 & 54 & 168 & 232 & 0.7 & $18 \cdot 5$ & 22.9 & 0.8 & $2 \cdot 0$ & $3 \cdot 5$ \\
\hline PP & 21 & & 6 & 204 & 255 & $1 \cdot 0$ & $29 \cdot 5$ & $29 \cdot 4$ & - & 3.9 & $5 \cdot 0$ \\
\hline BS & 222 & 106 & 108 & 408 & 537 & $4 \cdot 4$ & $44 \cdot 3$ & $54 \cdot 5$ & 3.4 & $6 \cdot 6$ & $7 \cdot 4$ \\
\hline JM & - & & 120 & 252 & 385 & $5 \cdot 0$ & $27 \cdot 3$ & $46 \cdot 3$ & $2 \cdot 3$ & 3.9 & $5 \cdot 3$ \\
\hline JP & - & & 132 & 456 & 499 & $3 \cdot 18$ & 57.0 & $57 \cdot 3$ & $6 \cdot 3$ & $19 \cdot 7$ & 20.7 \\
\hline
\end{tabular}


HISTAMINE IN GASTRIC ASPIRATE

The measurements of gastric juice, volume, acid and histamine, together with mucosal histamine concentrations are listed in the Table.

Figure 2 illustrates the output of acid and histamine in gastric juice collected during pentagastrin infusion. Pentagastrin infusion increases the amount of histamine in the gastric juice. In all except one fraction of gastric aspirate collected between 20 and 30 minutes after starting pentagastrin, the amount of histamine was significantly higher than the basal value. The two histogram profiles for histamine and acid in the gastric aspirate were similar in shape.

The output of histamine closely parallelled that of acid in gastric juice.

In 19 patients, the peak histamine output, calculated from the mean of the two highest 10 minute fractions, in the aspirate during pentagastrin stimulation correlated closely with the 'peak' acid output (PAO) $(r=0.79, \quad \mathrm{P}<0.001)$ (Fig. 3). The total histamine in the aspirate during pentagastrin infusion was related to the total acid secreted $(r=0.57, \mathrm{P}<0.02)$ (Fig. 4).

The changes of concentration of histamine in the gastric aspirate, as opposed to output, are illustrated in Fig. 5. In contrast with the changes in output, there is a significant fall in histamine concentration in the gastric juice during pentagastrin infusion. The increase in total 90 minute histamine output

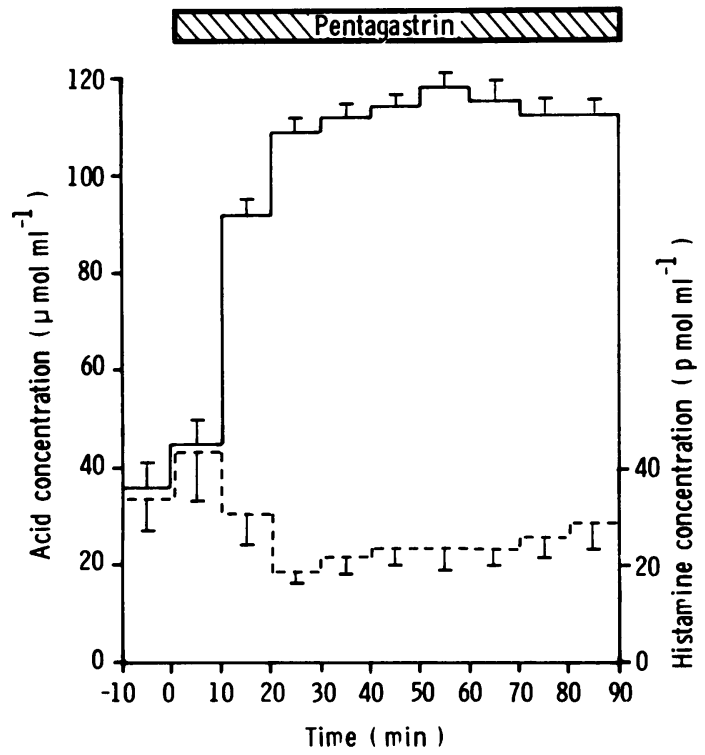

Fig. 5 Concentrations of acid and histamine in gastric juice during pentagastrin infusion. is therefore due to the rising volume of secretion. Total histamine output correlates with the total volume secreted $(r=0.54, \mathrm{P}<0.02)$.

\section{HISTAMINE IN PLASMA}

Figure 6 shows the changes in plasma histamine concentration illustrated against a background of acid secretion and gastric juice histamine. There was a peak between 20 to 30 minutes after pentagastrin infusion, with a mean $65 \%$ increase in the histamine concentration in the plasma followed by a rapid fall.

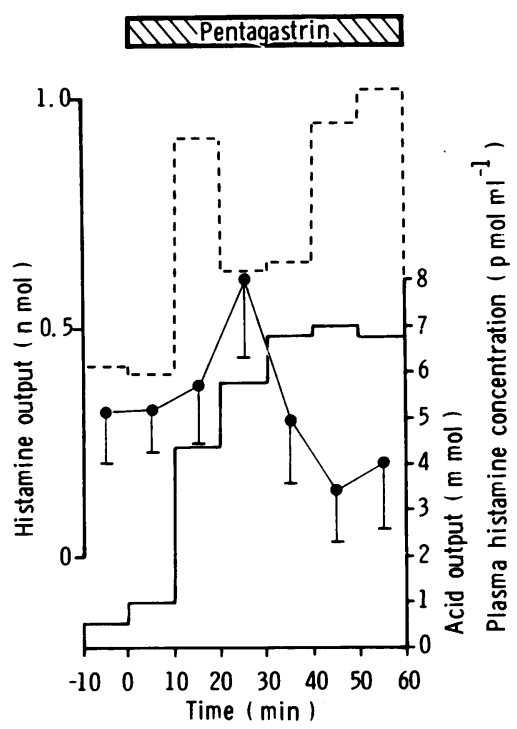

Fig. 6 Output of acid (solid line) and histamine (interrupted line) in gastric juice, and changes in plasma histamine (-) in six subjects during pentagastrin infusion.

MUCOSAL HISTAMINE

There was no apparent relationship between initial mucosal histamine concentration and acid secretion (basal acid output or PAO). Mucosal histamine also did not correlate with the increase in plasma histamine concentration during pentagsatrin infusion or with maximal gastric juice histamine.

\section{Discussion}

Recent advances in analytical methodology enable assay of histamine in biological specimens with high sensitivity and precision. The two most widely used methods are the fluorometric method developed by Lorenz and co-workers and the enzymatic 
isotopic method developed by Shaff and Beaven. ${ }^{12} 13$ Both methods were used in the present study. The fluorometric method is ideal for the assay of histamine in gastric mucosa and gastric aspirate samples. With the soluble glycoprotein in the aspirate removed by tungstate treatment, which reduces the viscosity of the sample to facilitate columnatography, even the longer histamine assay procedures for gastric aspirates can be completed within the same day of the experiment. However, for biological samples in which the histamine concentrations are very low, such as human blood plasma, the enzymatic isotopic method is more convenient. One advantage is that a large number of blood samples can be obtained from patients within a short period of experimental time as only a very small volume -in the present case, $0.1 \mathrm{ml}$ plasma-is needed for the assay. This method is more expensive and time consuming than the fluorometric method. A 30 times higher specific activity of the radiochemical than that quoted in the communication of Shaff and Beaven, and additional centrifugation and pipetting to remove the plasma protein before chloroform extraction, were needed to achieve the required sensitivity and reproducibility for the histamine assay in blood plasma. Thus, in the present study, histamine concentrations in the gastric mucosa and aspirate were assayed by the fluorometric method, while the plasma histamine concentration was determined by the enzymatic isotopic method.

Histamine has long been recognised as a gastric secretagogue. It is abundant in the gastric mucosa and, when given intravenously or subcutaneously, it has a powerful stimulatory action on parietal cells.

The relationship between acid production and peptic ulcer is well known. The development of fibregastroscopy has allowed study of the changes in mucosal histamine concentration in the stimulated state in patients with duodenal ulcer disease. In the present study, the production of gastric acid reduced the mucosal histamine concentration. The released histamine may be either secreted with acid into the lumen, or enter the circulation and be metabolised elsewhere.

Our results suggest that both mechanisms occur, as both gastric juice histamine and plasma histamine increase during pentagastrin infusion. The histamine concentration in the gastric aspirate increased to a peak of $160 \%$ of basal values, then fell to a sustained level significantly above basal values. This result suggest that an initial washout of histamine takes place, followed by a sustained secretion. These results support the findings of Lorenz et al, (1970) who demonstrated a similar rise. ${ }^{13}$ Depite the correlation of total histamine output with total volume secreted, these data suggest that histamine in the gastric juice is not a passive by-product of gastric secretion but studies of gastric acid secretion after stimulation by other methods are required to test this alternative hypothesis.

The detection of histamine release from the endogenous store during stimulation into the peripheral plasma is difficult when compared with that of gastric aspirate. Histamine is readily taken up by various tissues and mainly metabolised in liver and kidney. ${ }^{14}$ Caridis et al. ${ }^{15}$ failed to detect any increase in histamine concentration in venous blood during pentagastrin stimulated gastric acid secretion. However, with improved methodology, we detected an average increase of $65 \%$ in the histamine concentration in blood plasma at a period immediately after the first large rise in gastric juice histamine concentration and coincident with the plateau acid output.

We did not observe any correlation between mucosal histamine and either gastric juice histamine or the volume of gastric juice. Lorenz et al. ${ }^{16}$ have also observed a similar lack of correlation in duodenal ulcer and control patients.

We conclude that the association of histamine and gastric acid release shown in these studies is so close that there must be a functional relationship. Our data are compatible with the hypothesis that pentagastrin acts on the parietal cell indirectly by causing histamine release in the gastric mucosa, which, in turn, releases acid from the parietal cells.

We would like to thank Staff Nurse L Francis Reme, Mr J Barr, and Mr Kang Li for their skilled technical assistance and Mrs Iris Fisher for typing the manuscript.

\section{References}

${ }^{1}$ Kahlson G, Rosengren E, Svahn D, Thunberg R. Mobilization and formation of histamine in the gastric mucosa as related to acid secretion. J Physiol 1964; 174:400-16.

${ }^{2}$ Shore PA. Release of histamine from the stomach by vagus-stimulating drugs: association with gastric acid secretion. Fed Proc 1965; 24:1322-5.

3Johnson LR. Handbook of experimental pharmacology. Suppl, vol 18, Berlin: Springer, 1978.

${ }^{4}$ Thunberg, $\boldsymbol{H}$. Localization of cells containing and forming histamine in the gastric mucosa of the rat. Exp Cell Res 1967; 47:108-15.

${ }^{5}$ Smith AN. Histamine and acid secretion. $J$ R Col Surg Edinb 1960; 6:276-92.

${ }^{6}$ Hakanson R, Lilja B, Owman C. Cellular localization of histamine and monoamines in the gastric mucosa of man. Histochemie 1969; 18:74-86.

${ }^{7}$ Hakanson R, Lilja B, Owman C. Properties of a new system of amino-storing cells in the gastric mucosa of 
the rat. Eur J Pharmacol 1967; 1:188-99.

${ }^{8}$ Troidl H, Lorenz W, Rohde $\mathrm{H}$ et al. Histamine and peptic ulcer: a prospective study of mucosal histamine concentration in duodenal ulcer patients and in control subjects suffering from various gastrointestinal diseases. Klin Wochenschr 1976; 54:947-56.

${ }^{9}$ Baron JH. Clinical tests of gastric secretion. London: Macmillan, 1978.

${ }^{10}$ Shore PA, Burkhalter A, Cohn VH. A method for the fluorometric assay of histamine in tissues. J Pharmacol Exp Ther 1959; 127:182-6.

${ }^{11}$ Lorenz W, Doenicke A, Meyer R et al. An improved method for the determination of histamine release in man: its application in studies with propanidid and thiopentone. Eur J Pharmacol 1972; 19:180.

${ }^{12}$ Shaff HH, Beaven MA. Increased sensitivity of the enzymatic isotopic assay of histamine: measurement of histamine in plasma and serum. Anal Biochem 1974; 94:425-30.

${ }^{13}$ Lorenz W, Benesch L, Barth H. et al. Fluorometric assay of histamine in tissues and body fluids: choice of the purification procedure and identification in the nanogram range. $Z$ Metyl Chem 1970; 252: 94.

${ }^{14}$ Kahlson G, Rosengren E. Biogenesis and physiology of histamine. Monographs of the Physiological Society. London: Arnold, 1971: 99.

${ }^{15}$ Caridis DT, Porter JF, Smith G. Detection of histamine in venous blood from the stomach during acid secretion evoked by intravenous pentagastrin. Lancet 1968; 1:1281-2.

${ }^{16}$ Lorenz W, Troidl H, Barth H, Rohde H. Histamine, gastric secretion and peptic ulcer diseases: an attempt to define special source error and problems in clinicalbiochemical trials. In: Creutzfeldt W, ed. Cimetidine. Amsterdam-Oxford: Excerpta Medica, 1968: 10. 